\section{Mule Deer Fecal Group Counts Related to Site Factors on Winter Range ${ }^{1}$}

\section{ALLEN E. ANDERSON, DEAN E. MEDIN,2 AND DAVID C. BOWDEN}

Wildlife Researchers, Research Center, Colorado Division of Game, Fish and Parks, Fort Collins; and Assistant Professor, Department of Statistics, Colorado State University, Fort Collins.

\section{Highlight}

Measurements of 32 site factors on $931,100 \mathrm{ft}^{2}$, circular plots systematically distributed among lower, middle and upper Cache la Poudre, Colorado winter range study areas of about $\mathbf{5 0 0}$ surface acres each, were related to cumulative mule deer (Odocoileus hemionus) fecal groups counted on those plots (1963-65). Single and multiple linear regression and Chi-square analyses indicated that vegetative measurements, particularly antelope bitterbrush (Purshia tridentata) parameters, were the site factors most closely related to fecal group counts. These site factors accounted for about 10-13 percent in single linear regressions, and 8-20 percent in multiple linear regressions of the significant variation $\left(\mathbf{R}^{2}\right)$ in fecal group counts.

The distribution patterns of deer fecal groups countcd on sample plots are commonly used as indices of: (1) deer distribution within adjacent habitats (Julander, 1955; White, 1960; Reynolds, 1962a, 1966, 1969; McCaffery and Creed, 1969); and (2) deer response to habitat modification (Taber and Dasmann, 1958:69; Bramble and Byrnes, 1958; Reynolds, 1962b, 1964; Neff, 1968; Shafer and Liscinsky, 1968; Anderson, 1969; Krefting and Hansen, 1969; McCulloch, 1969; Patton, 1969; Wallmo, 1969). The validity of fecal group distribution patterns as an index to deer habitat preferences has not been experimentally verified and available data are in conflict. Direct, diurnal observations of mule deer distribution were found by White (1960) and Love-

\footnotetext{
${ }^{1}$ Contribution from Colorado Federal Aid Project W-105-R. We thank all individuals who assisted in the field, office, and manuscript review. Received February 9, 1971.

${ }^{2}$ Present address: U. S. Forest Service, Intermountain Forest and Range Experiment Station, Boise, Idaho.
}

less (1967) to generally support, and by Leckenby (1968) to refute, results obtained by fecal group counts. The efficient design of experiments to test discrete hypotheses relative to the validity of the technique would seem to require more detailed information on site factormule deer fecal group count relationships than presently available.

The objective of this exploratory study was to identify the site factors most strongly related to counts of mule deer fecal groups on individual plots.

\section{Methods}

Three study areas of about 500 acres each, were selected to include the elevational sequence of the major topographic and vegetative features of the lower (Area 1), middle (Area 2), and upper (Area 3) winter range of mule deer on the north side of the Cache la Poudre River within Roosevelt National Forest, northcentral Colorado.

Sampling was systematic. Mule deer fecal groups were counted and removed on each of $960,100-\mathrm{ft}^{2}$, circular plots by two observers. Our sampling design, fecal group search methods, fecal group criteria, and some statistical attributes of the fecal group counts are described in Bowden et al. (1969). The cumulative (1963-65) counts of mule deer fecal groups were used herein (Table 1).

The following measurements of abiotic and biotic site factors were made on, or immediately adjacent to, each of 960 fecal group plots.

\section{Abiotic Site Factors}

Plot elevations were read to the nearest $100 \mathrm{ft}$ from topographic maps $(1$ inch $=500 \mathrm{ft}, 20 \mathrm{ft}$ contour intervals) constructed for this study by a commercial engineering firm. Slope exposure was read to the nearest degree from true north with a Brunton compass. Slope gradient was read to the nearest percent with an Abney level. Radiation index is a theoretical quantity of solar irradiation and was read from the measured slope exposure and gradient of each plot as tabulated for lat $40 \mathrm{~N}$ by Frank and Lee (1966). Slope position was obtained by subjectively assigning and scoring each plot position as being in the lower (1), middle (2), and upper (3), onethird of its respective slope. Soil depth was subjectively judged and scored on the basis of ground surface characteristics as to whether developed soil depths were shallow (1), moderate (2), or deep (3). Soil texture was subjectively judged and scored on the basis of ground surface characteristics as to whether textures were coarse (1), medium (2), or fine (3).

\section{Biotic Site Factors}

Percent ground cover.-Defined as the proportion of the ground surface occupied by the vertical projection of live plant parts, both basal and aerial, plus that occupied by non-living matter such as litter, rock and dead plants. These components were sampled with vertical point quadrats (Fayle, 1959).

Shrub density.-All living shrubs, four or more inches in crown diameter and rooted within the $100-\mathrm{ft}^{2}$, circular fecal group plots were counted by species. Semi-woody species were not included in these counts.

Browse yields.-Oven-dry weights of forage were predicted directly from the estimated green weights of true mountainmahogany (Cercocarpus montanus), antelope bitterbrush (Purshia tridentata) and big sagebrush (Artemisia tridentata) (Hilmon, 1959; Blair, 1959). Forage was considered to be the current annual twig growth of true mountainmahogany, current annual twig growth and attached leaves for antelope bitterbrush, apparent annual twig growth and all leaves but ex- 
Table 1. Basic data relative to the mule deer fecal group counts, and concurrent estimates of browse yield and utilization.

\begin{tabular}{ccccc}
\hline \hline $\begin{array}{c}\text { Study } \\
\text { areas }\end{array}$ & $\begin{array}{c}\text { Surface acres } \\
\text { and elevation (ft) }\end{array}$ & \multicolumn{2}{c}{$\begin{array}{c}\text { End dates of } \\
\text { each sampling }\end{array}$} & $\begin{array}{c}\text { Time } \\
\text { interval } \\
\text { (days) }\end{array}$ \\
\hline 1 & 490.1 acrcs & $10-13-63$ & $5-27-64$ & 227 \\
& $5,710-7,230$ & $5-27-64$ & $10-6-64$ & 132 \\
& & $10-6-64$ & $5-17-65$ & 223 \\
2 & 509.2 acres & $10-21-63$ & $5-21-64$ & 213 \\
& $6,710-7,840$ & $5-21-64$ & $11-5-64$ & 168 \\
& & $11-5-64$ & $5-13-65$ & 189 \\
3 & 495.0 acres & $11-15-63$ & $5-27-64$ & 194 \\
& $7,440-8,800$ & $5-27-64$ & $11-6-64$ & 163 \\
& & $11-6-64$ & $5-27-65$ & 202 \\
\hline
\end{tabular}

cluding the flowering parts for big sagebrush. All such forage below a 5-ft height was estimated by species within the $100-\mathrm{ft}^{2}$, circular, fecal group plots. Estimates made on individual, tagged plants were summed for each $100-\mathrm{ft}^{2}$ fecal group. Sampling dates are given in Table 1.

Browse utilization.-Winter use of forage by deer was estimated in the late spring for the individual, tagged, true mountainmahogany, antelope bitterbrush, and big sagebrush plants using the ocular-estimate-by-average-of-plants methods of Pechanec and Pickford (1937). We assessed the percentage removal by weight for each plant with the "use-class" technique (Clark, 1941). Sampling dates are given in Table 1.

Additional site factors.-The presence or absence of plants, number of plants, percent ground cover, grams oven-dry yield, grams utilization, and percent utilization were derived from the vegetative measurements on a per plot basis for true mountainmahogany, antelope bitterbrush, and big sagebrush. The percent ground cover of fringed sage (Artemisia frigida), percent ground cover of cheatgrass (Bromus tectorum), number of shrub genera, and the number of herbaceous genera were similarly obtained. Thirty-two site factors were measured on each plot.

\section{Statistical Analyses}

Site factor measurements were complete for 360 plots on area 1, 298 plots on area 2, and 273 plots on 0.001 to avoid spuriously significant area 3. Simple correlation coefficients $(r)$ were calculated for all site factors $\left(X_{i}\right)$ measured on each of these plots versus their corresponding mule deer fecal group counts (Y). Because of the large number of correlation coefficients calculated, inferences are made at $\mathbf{P}<$ relationships. Stepwise, multiple linear regression analyses were used to estimate the relative importance of sample plot site factor measurements $\left(\mathrm{X}_{\mathrm{i}}\right)$ as influents on mule deer fecal group counts on these plots $(\mathrm{Y})$. For those 12 site factors which could be adequately categorized, Chi-square contingency tables were used to detect significant $(\mathrm{P}<0.05)$ differences among the category frequency distributions of mule deer fecal group counts.

\section{Results}

Simple correlation coefficients which differed significantly $(\mathrm{P}<$ $0.001)$ from zero correlation are listed in Table 2. Antelope bittcrbrush density and percent utilization accounted for the maximum variation $\left(\mathbf{R}^{2}=10-13\right.$ percent $)$ in

Table 2. Simple correlation coefficients of those counts of mule deer fecal groups $(\mathbf{Y})$ related to site factors $(\mathbf{X})$.

\begin{tabular}{clc}
\hline \hline $\begin{array}{c}\text { Study } \\
\text { area }\end{array}$ & \multicolumn{1}{c}{ Site factors } & $\begin{array}{c}\text { Correlation } \\
\text { coefficients }\end{array}$ \\
\hline 3 & Number of bitterbrush plants (per $\left.100-\mathrm{ft}^{2}\right)$ & 0.33 \\
3 & $\%$ utilization of bitterbrush & 0.36 \\
2 & $\%$ utilization of bitterbrush & 0.32 \\
\hline
\end{tabular}

fecal group counts. The results of the stepwise multiple linear regression analyses are listed by area in Table 3. Combinations of site factors accounted for 8-20 percent of the variation $\left(R^{2}\right)$ in fecal group counts.

Chi-square analyses revealed that elevation, slope gradient, slope exposure, soil depth, bare soil, density of antelope bitterbrush, and density of all shrub species were significantly $(P<0.05)$ related to the frequency distributions of mule deer fecal group counts. Maximum fecal group densities were significantly $(P<0.05)$ associated with higher elevations on the lower winter range study area and lower elevations on the upper winter range study area. Southeasterly slope exposures, 20-60 percent slope gradients, shallow or moderate soil depths, 50-60 percent bare soil, 1-6 antelope bitterbrush plants per plot, and 11-15 shrubs of all species per plot were each significantly $(\mathrm{P}<0.05)$ associated with maximum mean fecal group densities on one or more study areas. Antelope bitterbrush densities of 1-6 shrubs per plot and southeasterly exposures were both associated with the maximum mean fecal group densities of 2 groups per plot.

\section{Conclusions}

Both parametric and non-parametric analyses indicate that antelope bitterbrush in particular, and vegetation in general, were most closely related to mule deer fecal group counts. Significantly, current studies show that antelope bitterbrush was the major food item in stomach content samples from Cache la Poudre mule deer collected from the winter range at ap- 
Table 3. Multiple correlation coefficients of winter range mule deer fecal group counts $(Y)$ significantly $(P<0.01)$ related to that combination of site factors $(X)$ in which all the partial regression coefficients were significant $(P<0.05)$.

\begin{tabular}{|c|c|c|}
\hline Study area & $\begin{array}{c}\text { Multiple } \\
\text { correlation } \\
\text { coefficient }\end{array}$ & Independent site factors \\
\hline 1 & 0.40 & $\begin{array}{l}\text { elevation }(\mathrm{ft}) \\
\text { soil texture } \\
\% \text { ground cover of bitterbrush } \\
\% \text { of ground cover of cheatgrass } \\
\% \text { utilization of bitterbrush }\end{array}$ \\
\hline 2 & 0.37 & $\begin{array}{l}\text { radiation index } \\
\text { Grams utilization of mountainmahogany } \\
\text { Grams utilization of bitterbrush } \\
\text { No. shrub genera }\end{array}$ \\
\hline 3 & 0.45 & $\begin{array}{l}\text { bare soil }(\%) \\
\text { Grams utilization of mountainmahogany } \\
\text { Grams yield of bitterbrush } \\
\% \text { utilization of sagebrush }\end{array}$ \\
\hline
\end{tabular}

proximate weekly intervals, 196165 .

\section{Literature Cited}

ANDERson, A. E. 1969. 2,4-D, sagebrush, and mulc decr-cattle use of upper winter range. Colo. Div. Game, Fish and Parks Spec. Rep. 21. $21 \mathrm{p}$.

BlaIR, R. M. 1959. Weight techniques for sampling browse production on deer ranges, p. 26-31. In Techniques and methods of measuring understory vegetation. Proc. Symp. Tifton, Georgia, 1958. Southern Forest Exp. Sta., and Southeastern Forest Exp. Sta. 174 p.

Bowden, D. C., A. E. Anderson, And D. E. MEdin. 1969. Frequency distributions of mule deer fecal group counts. J. Wildl. Manage. 33:895905.

Bramble, W. C., and W. G. Byrnes. 1958. Use of a power line right-ofway by game after chemical brush control. Pa. Game News 29:17-25.

Clark, I. 1944. Field comparisons in estimating percentage utilization of range forage plants by direct percentage and by "use class" estimates. Utah Acad. Sci., Arts, and Letters. 21:7. (Abstract).

Fayle, D. C. F. 1959. The point contact method as a three-dimensional measure of ground vegetation. Forestry Chron. 35:135-141.

Frank, E. C., and R. Lee. 1966. Potential solar beam irradiation on slopes:tables for $30^{\circ}$ to $50^{\circ}$ latitude.
Arizona, 1967. Arizona Game and Fish Dept. Job Completion Rept. P-R Proj. W-78-R-12 WP 5, J-7. $129 \mathrm{p}$.

Patton, D. R. 1969. Deer and elk use of a ponderosa pine forest in Arizona before and after timber harvest. U. S. Forest Service, Rocky Mountain Forest and Range Exp. Sta. Res. Note RM-139. 7 p.

Pechanec, J. F., and G. D. Pickford. 1937. A comparison of some methods used in determining percentage utilization of range grasses. J. Agr. Res. 54:753-765.

REYNOLDS, H. G. 1962a. Use of natural openings in a ponderosa pine forest of Arizona by deer, elk and cattle. U. S. Forest Service. Rocky Mountain Forest and Range Exp. Sta. Res. Note 78. 4 p.

REYNolds, H. G. 1962b. Effect of logging on understory vegetation and deer use in a ponderosa pine forest of Arizona. U. S. Forest Service. Rocky Mountain Forest and Range Exp. Sta. Res. Note 80. 7 p.

REYNOLDS, H. G. 1964. Elk and deer habitat use of pinyon-juniper woodland in southern New Mexico. Trans. N. Amer. Wildl. and Nat. Resources Conf. 29:438-444.

REYNolds, H. G. 1966. Use of openings in spruce-fir forests of Arizona by elk, deer and cattle. U. S. Forest Service. Rocky Mountain Forest and Range Exp. Sta. Note 66. 4 p.

Reynolds, H. G. 1969. Aspen grove use by deer, elk and cattle in southwestern coniferous forests. U. S. Forest Service. Rocky Mountain Forest and Range Exp. Sta. Res. Note RM138. $4 \mathrm{p}$.

Shafer, E. L., JR., AND S. $\Lambda$. Liscinsky. 1968. Design and analysis for multiple-use studies of deer browse and timber production. U. S. Forest Service. Northcastern Forest Exp. Sta. Res. Paper NE-100. 25 p.

Taber, R. D., and R. F. Dasmann. 1958. The black-tailed deer of the chaparral; its life history and management in the North Coast range of California. California Dept. Fish and Game, Game Bull. 8. 163 p.

Wallmo, O. C. 1969. Response of deer to alternate-strip clear-cutting of lodgepole pine and spruce-fir timber in Colorado. U. S. Forest Service. Rocky Mountain Forest and Range Exp. Sta. Note RM-141. 4 p.

White, K. L. 1960. Differential range use by mule deer in the spruce-fir zone. Northwest Sci. 34:118-126. 